\begin{tabular}{|l|l|l||}
\hline \multicolumn{2}{|c|}{ PublisherInfo } \\
\hline \hline PublisherName & $:$ & BioMed Central \\
\hline \hline PublisherLocation & $:$ & London \\
\hline \hline PublisherImprintName & $:$ & BioMed Central \\
\hline \hline
\end{tabular}

\title{
Error-prone mitochondria
}

\begin{tabular}{|l|c|l||}
\hline \multicolumn{2}{|c|}{ ArticleInfo } \\
\hline \hline ArticleID & $:$ & 4472 \\
\hline \hline ArticleDOI & $:$ & $10.1186 /$ gb-spotlight-20020508-01 \\
\hline \hline ArticleCitationID & $:$ & spotlight-20020508-01 \\
\hline \hline ArticleSequenceNumber & $:$ & 138 \\
\hline \hline ArticleCategory & $:$ & Research news \\
\hline ArticleFirstPage & $:$ & 1 \\
\hline \hline ArticleLastPage & $:$ & 2 \\
\hline \hline & & RegistrationDate : 2002-5-8 \\
\hline ArticleHistory & $:$ & OnlineDate \\
\hline \hline ArticleCopyright & $:$ & BioMed Central Ltd2002-5-8 \\
\hline \hline ArticleGrants & $:$ & \\
\hline \hline ArticleContext & $:$ & 130593311 \\
\hline \hline
\end{tabular}




\section{Tudor Toma}

Email: t.toma@ic.ac.uk

Progressive external ophthalmoplegia (PEO) is an autosomal mitochondrial disorder associated with depletion of the mitochondrial genome and/or the accumulation of mutations and deletions within mitochondrial DNA. In the May 3 Journal of Biological Chemistry, Mikhail Ponamarev and colleagues from National Institutes of Health, North Carolina, show that a point mutation in the mitochondrial DNA polymerase ? (pol?) causes error-prone DNA synthesis in PEO (J Biol Chem 2002, 277:15225-15228).

Ponamarev et al.analyzed the effects of a codon 955 (Y955C) mutation in the pol ? gene on the kinetics and fidelity of DNA synthesis. They observed that the Y955C version of the enzyme retains a wild-type catalytic rate but suffers a 45-fold decrease in apparent binding affinity for the incoming nucleoside triphosphate. In addition, the full mutator effect of the Y955C substitution was revealed by genetic inactivation of the enzyme's exonuclease activity, and error rates for certain mismatches were elevated by $10-100$-fold.

"The error-prone DNA synthesis observed for the $\mathrm{Y} 955 \mathrm{C}$ pol ? is consistent with the accumulation of mitochondrial DNA mutations in patients with PEO," said the authors. "We predict a general mechanism in which point mutations are an early event in PEO and other mitochondrial diseases affecting the integrity of mitochondrial DNA."

\section{References}

1. Ponamarev MV, Longley MJ, Nguyen D, Kunkel TA, Copeland WC: Active site mutation in DNA polymerase ? associated with progressive external ophthalmoplegia causes error-prone DNA synthesis. $J$ Biol Chem 2002, 277:15225-15228., [http:/www.jbc.org/cgi/content/abstract/277/18/15225]

2. National Institutes of Health, [http://www.niehs.nih.gov/] 